\title{
Sosyal Bilgiler Öğretmenlerinin 5. Sınıf Sosyal Bilgiler Dersinin Coğrafya İçerikli Ünitelerine İlişskin Görüsşleri (Ankara İli Örneği)
}

\author{
Social Studies Teachers' Views on Geography Containing Units of 5th Grade \\ Social Studies Lessons (Example of Province of Ankara)
}

\author{
Mustafa AKSU* \\ Cemali SARI* ${ }^{* *}$
}

Öz: Bu çalışmanın amacı ilköğretimin II. kademesinde 2005'te uygulanmaya başlanan Sosyal Bilgiler Programının 5. sınıf coğrafya içerikli ünitelerine ilişkin Sosyal Bilgiler öğretmenlerinin görüşlerini almak, incelemek ve analiz etmektir. Araştırmanın evrenini Milli Eğitim Bakanlığı'na bağlı Ankara ili merkez ilçelerinde bulunan ilköğretim okullarında görev yapan Sosyal Bilgiler öğretmenleri oluşturmaktadır. Araştırmanın örneklemi tesadüfi atama yöntemiyle belirlenmiş, elde edilen veriler, SPSS 13.0 istatistik programı yardımıyla frekans, yüzde, analizi kullanılarak incelenmiştir. Araştırma sonuçlarının analizine göre, programda coğrafya içerikli konulara yeterli payın ayrıldığı, coğrafya içerikli konuların kendi içinde bütünlük gösterdiği, coğrafya kapsamlı ünitelerde içeriğin, öğrencide merak uyandırabilecek nitelikte olduğu, programda yer alan coğrafya içerikli kazanımların aralarında tutarlı, sonrakinin oluşumuna destek dizilimine kısmen sahip olduğu ortaya çıkmıştır. 5. sınıf Sosyal Bilgiler dersinin coğrafya içerikli ünitelerinden, "Bölgemizi Tanlyallm" ünitesinde "İklim ve İnsan Faaliyetleri" konusunun yeterli seviyede verildiği, "Ülkemizde Afetler" konusunun içeriğinin öğrencilerde farkındalık oluşturmaya yeterli olduğu, "Ürettiklerimiz" ünitesinde yer alan "İnsan ve Ekonomi" konusunun öğrencilerde farkındalık oluşturduğu belirtilmiştir. 5. sınıf Sosyal Bilgiler Öğretim Programı coğrafya içerikli konularında yaşanan öğrenim sürecinde, öğrenci merkezli eğitim ile materyal kullanımı ve kılavuz kitaptan yapılan etkinlikler dersin görselliğini arttırsa da zaman zaman geleneksel yöntemlere dönüldüğü ortaya çıkmıştır.

Anahtar sözcükler: Sosyal Bilgiler, Sosyal Bilgiler Öğretmeni, Coğrafya, Ankara

Abstract: The objective of this study is to monitor, analyze and take the views of Social Studies Teachers on Social Studies Programs which have been put into secondary school curriculum in 2005 and its effect on 5th Grades lessons containing subjects about Geography. According to analysis of the study, it has been observed that sufficient amount of Geography subjects are allocated in the program, there is integrity, the content of the units dealing with Geography are capable of evoking interest in students, acquisitions about Geography subjects in the Program are consistent with each other and partly support the subsequent unit ahead. In Social Studies Lessons of $5^{\text {th }}$ grades in which the units include subjects about Geography, climate and human activities subject in 'Lets get to know our region' unit is sufficiently explained, the content of 'Natural disasters in Turkey' unit can adequately create an awareness in students, 'Human beings and economy' subject in 'Our Products' unit builds awareness among students. It has been revealed that, in subjects about geography in Social Studies Lesson of 5th grades, although applying student centered education and relevant material and doing activities taken from the guide book enhance the visuality, traditional methods are also utilized.

Keywords: Social Studies, Social Studies Teacher, Geography, Ankara

\footnotetext{
* Ph.D., Akdeniz Üniversitesi, Eğitim Bilimleri Enstitüsü, İlköğretim Bölümü, Antalya. maksu007@gmail.com

** Doç. Dr., Akdeniz Üniversitesi, Edebiyat Fakültesi, Coğrafya Bölümü, Antalya. csari@akdeniz.edu.tr
} 


\section{Giriş}

Eğitimin başlıca hedefi, bireyin toplum içinde sosyalleşmesine katkıda bulunmak ve nitelikli vatandaşlar yetiştirilmesine zemin hazırlamaktır. Bu sebeple eğitim, başta bu amacı gerçekleştirmeyi ve hazırlanan programlar ile de belirlediği hedeflere ulaşmayı planlar. Türkiye'de de cumhuriyetin kuruluşundan itibaren belli zaman aralıkları ile hazırlanan programlar genel amaca ulaşmaya yöneliktir.

Günümüz dünyası iletişim ve bilgi çağını yaşamaktadır. Bilgi, iletişimin mesafeleri kısaltması ile genel kitlelere çok kısa sürede ulaşmakta ve buna paralel olarak kitleleri etkileyip değiştirmesine sebep olmaktadır. Bu değişim hem sosyal hem de ekonomik yapılarda kendini hissettirmektedir. Sosyo-ekonomik yapının değişimi toplumların eğitim sistemlerini etkilerken eğitim sistemleri bu hızlı değişimi yakalamak mecburiyetindedir. Ülkemizde de bu gelişmeler 1şı̆̆ında eğitim programları değiştirilmekte ve geliştirilmektedir (Tay 2004).

İletişimin gelişmesi ve bilgi patlamasıyla birlikte, değişen ve gelişen dünyada, etkili ve verimli vatandaşlar yetiştirmeyi amaç edinen Sosyal Bilgiler dersinin iki kapak ve dört duvar arasında bilginin aktarımı olarak değil; öğrencinin bilgiyi elde etmesi, bilimsel ve sistematik düşünme becerilerini kazanması olarak öğretilmesi gerekmektedir (Gelen 2002, 101). Genelde öğrencilerin gözünde Sosyal Bilgiler dersi sevimsiz, sıkıcı ve arındırılmamış, hazmedilmemiş ve yetişkinler dünyasına ait bilgilerin ezberci bir ders görüntüsündedir (Ata 2006, 72). İçerdiği disiplinler ve konulara bakıldığ zaman aslında hayatın kendisi olan Sosyal Bilgilerin bu anlamda değerlendirilmeyip geleneksel ders mantığıyla öğrenciye aktarılmaya devam ettiği sürece de bu görüntü ve alg1 değişmeyecektir. Özellikle de Sosyal Bilgilerin bir disiplini olan coğrafya öğretimi geleneksel yöntemlerle yapılmakta ve birçok kişi tarafindan coğrafya liselerde okutulan; üniversite sınavlarında 5-10 sorunun sorulduğu, ezbere dayalı, sıkıcı bir ders olarak algılanmaktadır (Şahin 2003). Tüm bu sebeplerle hali hazırda uygulamada olan 2005 Sosyal Bilgiler programının coğrafya içeriğinin uygulanabilirliğinin sorgulanması gerekmektedir. Eğitim sisteminin uygulayıcısı ve merkezi konumunda sayılan öğretmenlerin 2005 Sosyal Bilgiler programının coğrafya içeriğinin uygulamadaki etkililiğinin belirlenmesine yönelik alg1larını tespit etmektir.

\section{Araştırmanın Önemi}

Eğitim sistemleri ve doğal olarak öğretim ve ders programları, günümüz dünyasında bireysel, toplumsal, ekonomik vb. gibi alanlarda yaşanan hızlı değişim ve gelişimlerden önemli ölçüde etkilenmiştir. Toplumsal gelişim, değişim ve dönüşümde, eğitimde program geliştirme çalışmaları stratejik bir öneme sahiptir. Nitekim geliştirilen programların, çağın gereksinimlerini karşılayıcı nitelikte olması, ön uygulamalarının yapılarak hatalardan arındırılması, güvenilir ve geçerli hale getirilmesi oldukça önemlidir. Söz konusu değişim ve gelişmeler Sosyal Bilgiler ders programlarında da değişiklikler yapmayı zorunlu kılmıştır. Çünkü toplumsal değişimlere ayak uydurabilecek bireylerin yetiştirilebilmesi ancak çağın şartlarına uygun bilimsel bilgiler ışığında hazırlanmış programlar sayesinde gerçekleştirilebilecektir. Geleceğe yönelik hızla değişen dünyada Sosyal Bilgiler öğretmenleri ve alan uzmanları geleceği iyi okumak, çocuk ve gençlerin zamanın getireceği yeni durumlara etkin bir şekilde uyum sağlamalarına yardımcı olmak konusunda ister istemez eğitim ve öğretim anlayışlarını yeniden gözden geçirmek zorundadır. Tüm bu sebeplerle beşinci sınıf Sosyal Bilgiler programının uygulamadaki etkililiğinin bilimsel araştırmalarla belirlenmesinin hem Sosyal Bilgiler ders programlarını geliştirme çalışmalarına hem de bu alanda araştırma yapmak isteyen araştırmacılara katkı sağlayacağı düşünülmektedir. 


\section{Sosyal Bilgiler}

Türkiye'de ilköğretim kademesinde bir ders olarak okutulan Sosyal Bilgiler, gerek Türk Millî Eğitim Sisteminin genel amaçlarını gerçekleştirmede gerekse bir öğretim programı olarak belirlenen hedeflere ulaşmak için bu görevi yerine getirmeye çalışmaktadır. Hazırlanan (2004) ilköğretim programında Sosyal Bilgiler dersinin vizyonu da şu şekilde belirtilmiştir:

- Sosyal bilimlere ait kavram ve yöntemleri kullanan,

- Çağın gerektirdiği temel bilgi, beceri ve değerlerle donanmış,

- Etkin, üretken, hak ve sorumluluklarını bilen ve kullanan yurttaşlar yetiştirmektir (MEB 2005, 45).

Tüm bunlardan anlaşılacağı üzere aslında Sosyal Bilgiler dersi öneminin yanında kazanımları ile de dikkat çekmektedir.

Özdemir (2006, 7), araştırmasında NCSS'nin (1992) Sosyal Bilgiler dersinin amaçlarını şu şekilde açıkladığını ifade etmektedir:

- Dünyada görülen önemli gelişmelere karşı duyarlı olma,

- Okul içinde ve toplumda katılım ve gözlem etkinliklerini gerçekleştirme,

- Demokratik anlayışa uygun karar verme becerilerini kazandırma,

- Bireysel ve kültürel kimlik anlayışını toplumsal yaşam kavramı bağlamında tanımlama.

Görüldüğü gibi Sosyal Bilgiler dersine ilişkin tanımlar ile ulusal ve evrensel hedefler incelendiğinde, Sosyal Bilgiler dersi, ilköğretim basamağında öğrencilere gerekli temel bilgi, beceri ve tutumları kazandırarak onları toplumsal yaşama hazırlamakta ve bu yönüyle temel ders niteliği taşımaktadır. Sosyal Bilgiler dersi, bilgiyi hazır olarak almak yerine, işbirliği ve sorumluluk anlayışına sahip, bilgiye kendi gayreti ile ulaşan, ulaştığ 1 bilgileri yorumlayıp değerlendiren ve kullanan bireyler yetiştirmeyi hedeflemektedir.

\section{Coğrafya}

Bugüne kadar coğrafyanın pek çok tanımı yapılmıştır. İlk kez "gegraphe" ya da "geographia" yani coğrafya terimi eskiçağ Yunan düşünürlerinden İskenderiye Coğrafya Ekolü’nün kurucusu Eratosthenes tarafindan kullanılmıştır (Doğanay \& Sever 2011, 2). Bugünkü çağdaş coğrafya bilimi, içerik olarak yeryüzünü incelemekte ve yeryüzünde meydana gelen olaylar arasındaki bağlantıları, bunların dağılışını ve bu dağglışın sebeplerini araştırmaktadır. Modern coğrafî düşüncede sadece yaşadığımız dünyanın anlatımıyla ilgilenildiğini düşünmek yanıltıcı olur. Coğrafya biliminin araştırma konusunu oluşturan olaylar ve olgular açıklanmakla yetinilmez, bu açıklamaların yanında bunların nedenleri, sonuçları, insanla olan ilişkileri ve yeryüzünün genelinde veya bir bölümündeki dağılım ve düzenleri de araştırılır (Atalay 1994).

Coğrafya denilince doğal ve sosyal bilimleri kapsayan çeşitli bakış açılarını, yaklaşımları ve belirli konu alanlarını içeren son derece geniş bir disiplin akla gelmektedir. Coğrafyanın araştırma konuları şu başlıklar altında belirtilebilir: Yaşadığımız çevrenin fizikî özellikleri, insan-doğal çevre etkileşimi ile ortaya çıkan beşerî ve ekonomik faaliyetlerimiz, ortaya koyduğumuz kültürel varlıklar, yine insan-doğal çevre etkileşimi sonucu ortaya çıkan çevre sorunları, doğal ortamın bizler üzerindeki var olan olumsuz etkileri (doğal afetler) ve son olarak doğal ortam ile insanlar arasındaki etkileşim sonucunda ortaya çıkan çeşitli çevre sorunları (Şahin 2003). Coğrafya disiplini sadece lokasyonların yerlerini ve isimlerini öğrenme, bu yerlerin bulundukları coğrafî bölgeleri haritalarda gösterme faaliyeti değildir. $\mathrm{Bu}$ ders öğrencilerin çevreleriyle ilgili anlayış geliştirmelerine de fayda sağlar (Karabağ 1998).

Sosyal Bilgiler dersi, çevresinde meydana gelen olayları değerlendirebilen ve sağlıklı sonuçlara ulaşabilen etkin vatandaşlar yetiştirmeyi hedef almaktadır. $\mathrm{Bu}$ amacın 
gerçekleştirilmesinde Sosyal Bilgilerin temel disiplinlerinden birisi olan coğrafya ayrı bir yere sahiptir. Çünkü coğrafya, öğrencilerin tarihte yaşanmış olayların yaşandığı mekânın coğrafî özelliklerinin bilinmesi, geçmişte yaşanan askerî, siyasî, sosyal ve ekonomik kökenli olayların analiz edilmesi ve daha kalıcı öğrenmelerin gerçekleşmesi bakımından çok önemlidir. Coğrafî bilgi, bireylerin yakın çevresinden başlayarak farklı yerler, bölgeler ve kültürlere yönelik dünya algısı oluşturmalarına, mekânsal analizler yaparak yaşadığ çevreye yönelik projeler geliştirmelerinde önemli bir işleve sahiptir (Gençtürk 2009).

\section{Sosyal Bilgiler Dersinde Coğrafya İçerikli Konuların Öğretimi}

Coğrafî̀ bilgiyi öğrenme sürecinde de iki temel unsur vardır. Birincisi öğrenme, ikincisi ise öğretmedir. Öğrenme öğretme sürecinde verimliliğin artırılması her şeyden önce öğrenmenin bireyde nasıl meydana geldiğinin anlaşılmasıyla mümkündür. Öğretme, bu sürecin detaylı bir şekilde incelenmesi ve sonuçta bireyin davranışlarındaki değişmelerin saptanmasıyla başarılı olur. Ancak diğerlerinden farklı olarak coğrafya öğretimi sırasında, konunun içeriğine göre bazı yöntem-teknikler ile araç-gereçlerin kullanılması öne çıkabilir. Örneğin; Fen Bilgisi dersleri için deneysel çalışmalar ön plana çıkmaktayken, Coğrafya derslerinde gözlem veya gezi yapmak ilk sıralarda yer almaktadır. Bu özellikleri göz önünde bulundurmak ve coğrafya öğrenme-öğretme sürecini buna göre değerlendirmek bir zorunluluktur. Temelde pozitif bir bilim olan coğrafya, bazı araştırma konuları bakımından fen bilimlerine, bazılarında ise sosyal bilimlere yaklaşır. Uyguladığı düşünce sistemini ilkeleri ile şekillendirir ve coğrafî mantıkla yorumlayarak toplumun sosyal, ekonomik ve teknik sorunlarını çözümlemeyi kolaylaştıran öneriler getirir (Doğanay 1989). Bu sebeple, coğrafyanın eğitim sistemimiz içinde ilköğretimden üniversiteye kadar aslında çok özel bir yerinin olması gerekmektedir. Bugün, ülkemizde de beklentimiz iyi bir coğrafya eğitim sürecinden geçen insanlarımızın problem çözme becerilerinin gelişmiş olmasidir.

\section{5. İlköğretimde Coğrafya Disiplinli Konuların Öğretiminin Önemi}

İyi bir coğrafya bilgisine sahip bireyler, Türkiye'nin ve dünyanın karşı karşıya olduğu temel sorunları (iklim değişimi, enerji bağımlılığı, savaşlar ve bölgesel karışıklıklar, küreselleşme, ulusal ve uluslararası terör vb.) doğru bir şekilde algılama potansiyeline sahip olacaklardır. Hem Türkiye hem de Dünya ölçeğinde farklı kültürleri tanımak, onların özelliklerinden haberdar olabilmek ve onlarla ortak bir yaşam kültürü oluşturabilmek için bireyin temel coğrafî bilgilere sahip olması önemli bir rol oynayacaktır. Lise öğrenimi sırasında coğrafî bilgi sistemleri, küresel yer belirleme sistemi ve diğer harita teknolojileri ile ilgili bilgi ve becerilerin öğrencilere kazandırılabileceği yegâne ders Coğrafya dersidir. Doğal afetlerin etkisini azaltmak, doğal afetlerle yaşama ve korunma kültürü temelde coğrafya bilgileri sayesinde kazanılabilmektedir. Coğrafya dersi, doğal ve beşerî bilimler arasında birleştirici bir köprü rolü oynadığı için öğrencilerin diğer dersleri yapılandırmacı yaklaşım çerçevesinde zihinlerine daha anlamlı bir şekilde yerleştirebilmelerinde coğrafî bakış açısının önemli bir rol oynayacağı söylenebilir. (Kocalar \& Demirkaya 2014, 126).

Günümüzde teknolojinin ve özellikle internetin iş ve sosyal hayatımızın büyük bir çoğunluğunu kapladığını, evlerde, iş yerlerinde bilgisayar ve internet kullanımının temel ihtiyaçlar listesine girmesine rağmen, çağın gelişimlerinin en ileri seviyede takip etmesi gereken okulların bu konuda çok gerilerde kalması ve günlük eğitim öğretim sürecinde öğrencinin teknolojiden çeşitli (araç-gereç eksikliği, idarecilerin kaynakları kullanıma açmaması, öğretmenlerin teknoloji kullanımında yeterli donanıma ve özgüvene sahip olmaması vb.) sebeplerle uzaklaştırılmaya çalışılması da üzerinde dikkatle durulması ve çözüm üretilmesi gereken bir konudur. 
Coğrafya, öğrencilerin çevrelerinde olanları anlamalarına ve insanın çevre ile etkileşimi hakkında bir anlayış geliştirmelerine yardımcı olur. Yerlerin isimlerini, lokasyonlarını ve özelliklerini bilmek, coğrafyanın temelini oluşturan unsurlardır. Bu da çok büyük ve oldukça büyüleyici öğrenme alanının bir parçasıdır (Efe 1996).

Bugün artık coğrafya, insanoğlunun günlük hayatında sık sık başvurduğu ve yararlandığı bir bilimdir. Her kişi günlük hayatı içinde verimli çalışabilmek için işiyle ilgili bilgi ve becerilerle birlikte, çevresini yurdunu ve dünyayı tanımak ihtiyacındadır. Coğrafyanın esas görevi, Dünya ile ilgili bilgi ve gerçekleri sunmaktır. Öğrencileri yerleşim, yer ve yerler arası ilişkiler, göçler ve bölge kavramlarıyla tanıştırmak çevreye karşı olan tutum değerleri incelemek ve onlara zihinsel pratik beceriler vermekte Coğrafya dersinin görevlerindendir. İlkokuldaki coğrafya eğitimi öğrencilere kendi yaşadıkları bölgenin yanı sıra, Türkiye'nin diğer bölgelerini de araştırıp anlayabilmeleri için bulunmaz bir olanak sağlar. Öğrenciler sadece coğrafî bilgi edinmekle kalmayıp bunları toplama, yorumlama ve tanımlama gibi becerilerde kazanmış olacaklardır (Barth \& Demirtaş 1997, 4-17).

\section{5. Sınıf Sosyal Bilgiler Programında Coğrafya İçerikli Öğrenme Alanları ve Ünitelerin Dağılımı}

Hangi seviyede olursa olsun gerek ilköğretim Sosyal Bilgiler dersi kapsamındaki coğrafya disiplinli konuların gerekse orta öğretimde ayrı bir disiplin olarak Coğrafya derslerinin öğretiminde içeriğin seçiminde önemsenmesi gereken bir kısım ölçütlere ihtiyaç vardır. İçeriğin seçiminde yararlanılabilecek ölçütler şöyle sıralanabilir:

1. İçeriğin evrensel anlamlılı̆̆ ve bilimsel geçerliliği var mıdır?

2. İçerik, kültürel ve sosyal bakımdan anlamlı mıdır?

3. İçerik, öğrencilerin gelişim düzeyine, ilgilerine ve ihtiyaçlarına yönelik midir?

4. İçerik, anlayışta genişlik ve derinliğe gelişme sağlamakta mıdır?

$\mathrm{Bu}$ tür sorulara verilecek cevaplar, coğrafya öğretiminde içeriğin seçiminde temel oluşturabilecek ölçütler konusunda görüş kazandırır (Engin Akbaş \& Geçtürk 2003, Akt. Kahriman 2008, 27).

Geri dönüşüm, tasarruf, bilinçli tüketim, suyun önemi ve su kaynaklarının korunması, sürdürülebilir kalkınma vb. gibi günümüz dünyasının çok önemli konularına Coğrafya ders kitaplarında mutlaka yer verilmesi gerekmektedir. Gelecekte ülkemizin kaynaklarını kullanacak ve değerlendirecek öğrencileri bilgiyle donatırken, bu donanımın en önemli parçalarından biri olan coğrafya bilgisinin yetersiz kaldığını gözlemekteyiz (Çalışkan 2002, 136-137 Akt. Kahriman 2008, 27).

Sosyal Bilgiler Programında "Insanlar, Yerler ve Çevreler", "Üretim, Dă̆ıtım, Tüketim" ve "Küresel Bağlantılar" öğrenme alanları coğrafya disiplini ile doğrudan ilişkilendirilebilir. Araştırmamızın da konusunu oluşturan 5. sınıf Sosyal Bilgiler Programı coğrafya içerikli üniteler "Bölgemizi Tanıyalım", "Ürettiklerimiz", "Hepimizin Dünyası"dır. Süre açısından bu ünitelerin 5. sınıf üniteleri arasındaki payı $\% 39$ 'dur.

\section{Yöntem}

Araştırmada, ilköğretim okullarında 2005-2006 eğitim öğretim yılından itibaren uygulanmaya başlanan 2005 Sosyal Bilgiler 5. sınıf programının kazanım, içerik, öğretim süreci, değerlendirme ve programın geneli hakkında Sosyal Bilgiler öğretmenlerinin görüşlerine dayalı olarak değerlendirilmesi amaçlanmıştır.

$\mathrm{Bu}$ çalışmada nicel ve nitel araştırma yöntemlerinin birlikte kullanıldığı karma araştırma modeli (mixed method); karma modellerden de zenginleştirilmiş desen kullanılmıştır. 
Çalışmanın nicel araştırmasında tarama modeli esas alınmış olup araştırma tarama modellerinden genel tarama modeline daha uygundur.

$\mathrm{Bu}$ araştırmanın evrenini 2014-2015 eğitim öğretim y1lında Ankara ili merkez ilçelerinde görev yapan Sosyal Bilgiler öğretmenleri oluşturmaktadır. Örneklemini ise Ankara ili merkez ilçelerinde bulunan ilköğretim okullarında görev yapan 95 Sosyal Bilgiler öğretmeni oluşturmaktadır. Bu araştırmanın örneklemi tesadüfî atama yöntemiyle belirlenmiştir.

Sosyal Bilgiler öğretmenlerinin görüşlerini almak amacıyla üç bölümden oluşan bir anket geliştirilmiştir: Birinci bölüm, kişisel bilgiler ile sınıfın durumuna yönelik sorular; ikinci bölüm, Sosyal Bilgiler Programına ve Coğrafya içerikli ünitelerine ilişkin sorular; üçüncü bölüm ise programın öğretimdeki uygulamaları ile ilgili görüşlerini almaya yönelik sorulardan oluşmaktadır. Anketin ikinci bölümünde, öğretmenlerin programla ilgili görüşlerini almaya yönelik Likert tipi geliştirilen ölçekli soru çeşitleri yer almıştır.

Hazırlanan ölçeğin geçerliliği için, bir alan uzmanı, bir ölçme ve değerlendirme uzmanı ve bir dil uzmanının görüşlerine başvurulmuştur. Testin güvenirlik tespiti için bir ön uygulama yapılmış, yapılan ön uygulamanın Croanbach alpha güvenirlik katsayısı 0,916 değerinde hesaplanmıştır. Verilerin analizinde SPSS paket programı kullanılmıştır.

Ölçeğin örnekleme uygulanması: 48 maddeden oluşan deneme ölçeğine pilot uygulama olarak örnekleme alınan öğretmenlerin dışında 25 Sosyal Bilgiler öğretmenine ulaşılarak, elde edilen veriler değerlendirilmiştir. Ölçek toplamda 95 Sosyal Bilgiler öğretmenine uygulanmış ve tamamı geçerli olarak kabul edilmiştir.

Anketin uygulanması sonucunda elde edilen 95 anket formu incelenmiş ve tamamı değerlendirmeye alınmıştır. Elde edilen nicel veriler SPSS 13.0 programında değerlendirilmiş, nitel veriler ise betimsel analiz yöntemi ile yorumlanmıştır. Sosyal Bilgiler öğretmenlerinin, Sosyal Bilgiler Programının coğrafya içerikli ünitelerine dair görüşlerini belirlemek üzere yüzde ve frekans analizi uygulanmıştır. Programda alınan frekans ve yüzdeler tablolaştırılarak okunmuş ve yorumlanmıştır.

Araştırmamızda, Sosyal Bilgiler öğretmenlerinin ilköğretim 5. sınıf Sosyal Bilgiler Programı ve programın coğrafya içerikli üniteleri ile ilgili görüşleri arasında istatistiksel olarak anlamlı bir farklılık olup olmadığına bakmak amacıyla cinsiyet değişkeni bağımsız t-testi, hizmet süreleri değişkeni ve mezun olunan bölüm türü değişkeni için One-Way ANOVA sonuçlarına göre analiz edilmiştir. One Way Anova analizinde anlamlılık düzeyi olarak 0,05 seçilmiştir.

\section{Bulgular}

5. sınıf Sosyal Bilgiler dersinin coğrafya içerikli ünitelerinin Sosyal Bilgiler öğretmenlerinin görüşlerine göre değerlendirilmesini konu alan bu çalışmada elde edilen bulgular şöyledir;

Tablo 1'de görüldüğü üzere araştırmaya katılan öğretmenlerin hizmet süreleri ve cinsiyet dağılımına bakıldığg zaman hizmet süresi 6-10 yıl arasında görev yapan kadın öğretmenlerin \%60'1 Sosyal Bilgiler Öğretmenliği, \%40'1 Coğrafya mezunlarından oluşmakta iken erkek öğretmenlerin \%76's1 Sosyal Bilgiler Öğretmenliği, \%12'si Coğrafya Öğretmenliği, \%12'si Tarih Öğretmenliği mezunlarından oluşmaktadır. 
Tablo 1. Öğretmenlerin Hizmet Süreleri, Cinsiyet ve Mezun Oldukları Bölüme Göre Frekans ve Yüzde Dağılımları

\begin{tabular}{|c|c|c|c|c|c|c|c|c|}
\hline \multirow[b]{2}{*}{$\begin{array}{l}\text { Hizmet } \\
\text { Süreleri }\end{array}$} & \multirow[b]{2}{*}{$\begin{array}{l}\text { Cinsiy } \\
\text { et }\end{array}$} & \multirow[b]{2}{*}{ Frekans ve \% } & \multicolumn{5}{|l|}{ Branș } & \multirow[b]{2}{*}{ Toplam } \\
\hline & & & $\begin{array}{l}\text { Sosyal Bilg. } \\
\text { Öğrt. }\end{array}$ & $\begin{array}{l}\text { Coğrafya } \\
\text { Öğrt. }\end{array}$ & $\begin{array}{l}\text { Tarih } \\
\text { Öğrt. }\end{array}$ & Coğrafya & Tarih & \\
\hline \multirow{4}{*}{$0-1$ Y 1} & \multirow{2}{*}{ Kadın } & Frekans & & & & & & \\
\hline & & $\%$ & & & & & & \\
\hline & \multirow{2}{*}{ Erkek } & Frekans & 3 & & & & & 3 \\
\hline & & $\%$ & 100 & & & & & 100 \\
\hline \multirow{4}{*}{$1-5 Y_{1} l$} & \multirow{2}{*}{ Kadın } & Frekans & 5 & & & & & 5 \\
\hline & & $\%$ & 100 & & & & & 100 \\
\hline & \multirow{2}{*}{ Erkek } & Frekans & 12 & & & & 3 & 15 \\
\hline & & $\%$ & 80 & & & & 20 & 100 \\
\hline \multirow{4}{*}{$6-10 Y_{1}$} & \multirow{2}{*}{ Kadın } & Frekans & 6 & & & 4 & & 10 \\
\hline & & $\%$ & 60 & & & 40 & & 100 \\
\hline & \multirow{2}{*}{ Erkek } & Frekans & 19 & 3 & 3 & & & 25 \\
\hline & & $\%$ & 76 & 12 & 12 & & & 100 \\
\hline \multirow{4}{*}{$11-15$ Y1l } & \multirow{2}{*}{ Kadın } & Frekans & 7 & & 2 & & & 9 \\
\hline & & $\%$ & 77,8 & & 22,2 & & & 100 \\
\hline & \multirow{2}{*}{ Erkek } & Frekans & 10 & & 5 & & & 15 \\
\hline & & $\%$ & 66,7 & & 33,3 & & & 100 \\
\hline \multirow{4}{*}{$16-20 Y_{1} l$} & \multirow{2}{*}{ Kadın } & Frekans & 3 & & 1 & 3 & & 7 \\
\hline & & $\%$ & 42,9 & & 14,3 & 42,9 & & 100 \\
\hline & \multirow{2}{*}{ Erkek } & Frekans & & 3 & & & & 3 \\
\hline & & $\%$ & & 100 & & & & 100 \\
\hline \multirow{4}{*}{$21-30$ Yil } & \multirow{2}{*}{ Kadın } & Frekans & & 3 & & & & 3 \\
\hline & & $\%$ & & 100 & & & & 100 \\
\hline & \multirow{2}{*}{ Erkek } & Frekans & & & & & & \\
\hline & & $\%$ & & & & & & \\
\hline
\end{tabular}

11-15 yıl arasında görev yapan kadın öğretmenlerin \%77,8'i Sosyal Bilgiler Öğretmenliği, \%22,2'si Tarih Öğretmenliği mezunlarından oluşmakta iken erkek öğretmenlerin \%66,7'si Sosyal Bilgiler Öğretmenliği, \%33,3’ü Tarih Öğretmenliği mezunlarından oluşmaktadır.

Sosyal Bilgiler Öğretmenlerinin, 5. Sınıf Sosyal Bilgiler Öğretim Programının Coğrafya İçerikli Ögelerine İliş̧kin Görüşleri Nelerdir?

Programın değerlendirilmesi ile ilgili olarak Tablo 2'de görüldüğü üzere "Bu ögrretim programı eğitim ile ilgili düşüncelerimi olumlu yönde değiştirdi" sorusuna verilen cevapların dağılımına bakıldığı zaman \%48,4'ünü katılanlar, \%27,4'ünü kararsızlar, \%24,2'sini katılmayanlar oluşturmaktadır. Buna göre öğretmenlerin çoğunluğu "Bu ögretim programı"nın eğitim ile ilgili düşüncelerini olumlu yönde değiştirdiğini ifade etmektedir.

"Öğretim programında coğrafya konularına yeterli pay ayrılmıştır" sorusuna verilen cevaplara bakıldığında \%50,5'ini katılanlar, \%11,6'sını kararsızlar, \%37,9'unu katılmayanlar oluşturmaktadır. Buna göre örneklemde yer alan öğretmenler az bir farkla da olsa programda coğrafya içerikli konulara yeterli payın ayrıldığını düşünmektedir.

"Programda coğrafya içerikli konular kendi içinde bütünlük göstermektedir" sorusuna verilen cevaplara bakıldığı zaman \%50,5'ini katılanlar, \%14,7'sini kararsılar, \%34,8'ini katılmayanlar oluşturmaktadır. Buna göre örneklemde yer alan öğretmenler programda yer alan coğrafya içerikli konuların kendi içinde bütünlük gösterdiğini ifade etmektedir. 
Tablo 2. Programın Değerlendirilmesi-Sosyal Bilgiler Öğretmenlerinin 5. Sinıf Sosyal Bilgiler Programının Coğrafya İçerikli Ögelerine İlişkin Görüşleri

\begin{tabular}{|c|c|c|c|c|c|c|c|c|c|c|c|c|}
\hline & \multicolumn{2}{|c|}{ 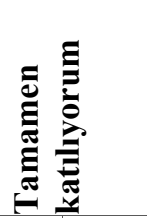 } & \multicolumn{2}{|l|}{ 咅 } & \multicolumn{2}{|l|}{ 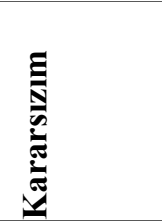 } & \multicolumn{2}{|l|}{ 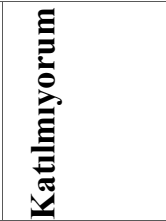 } & \multicolumn{2}{|c|}{ 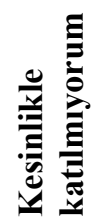 } & \multicolumn{2}{|c|}{$\frac{\Xi}{\frac{\Xi}{\sigma}}$} \\
\hline & $\mathrm{F}$ & $\%$ & $\mathrm{~F}$ & $\%$ & $\mathrm{~F}$ & $\%$ & $\mathrm{~F}$ & $\%$ & $F$ & $\%$ & $\mathrm{~F}$ & $\%$ \\
\hline $\begin{array}{l}\text { Bu öğretim programı eğitim } \\
\text { ile ilgili düš̈uncelerimi } \\
\text { olumlu yönde değiştirdi. }\end{array}$ & 13 & 13,7 & 33 & 34,7 & 26 & 27,4 & 19 & 20 & 4 & 4,2 & 95 & 100 \\
\hline $\begin{array}{l}\text { Öğretim programında } \\
\text { Coğrafya konularına yeterli } \\
\text { pay ayrılmıştır. }\end{array}$ & 13 & 13,7 & 35 & 36,8 & 11 & 11,6 & 31 & 32,6 & 5 & 5,3 & 95 & 100 \\
\hline $\begin{array}{l}\text { Programda coğrafya içerikli } \\
\text { konular kendi içinde } \\
\text { bütünlük göstermektedir. }\end{array}$ & 16 & 16,8 & 32 & 33,7 & 14 & 14,7 & 24 & 25,3 & 9 & 9,5 & 95 & 100 \\
\hline $\begin{array}{l}\text { Coğrafya kapsamlı } \\
\text { ünitelerde içerik, öğrencide } \\
\text { merak uyandırabilecek } \\
\text { niteliktedir. }\end{array}$ & 17 & 17,9 & 33 & 34,7 & 28 & 29,5 & 9 & 9,5 & 8 & 8,4 & 95 & 100 \\
\hline $\begin{array}{l}\text { Programdaki coğrafì içerikli } \\
\text { beceriler her öğretmenin } \\
\text { doğru anlayabileceği } \\
\text { şekilde açık ve nettir. }\end{array}$ & 13 & 13,7 & 56 & 58,9 & 14 & 14,7 & 8 & 8,4 & 4 & 4,2 & 95 & 100 \\
\hline $\begin{array}{l}\text { Coğrafya içerikli becerilerin } \\
\text { seçimi doğru yapılmıştır. }\end{array}$ & 14 & 14,7 & 38 & 40 & 26 & 27,4 & 12 & 12,6 & 5 & 5,3 & 95 & 100 \\
\hline $\begin{array}{l}\text { Programda yer alan } \\
\text { coğrafya içerikli kazanımlar } \\
\text { aralarında tutarll, } \\
\text { sonrakinin oluşumuna } \\
\text { destek dizilimine sahiptir. }\end{array}$ & 16 & 16,8 & 30 & 31,6 & 13 & 13,7 & 32 & 33,7 & 4 & 4,2 & 95 & 100 \\
\hline
\end{tabular}

"Coğrafya kapsaml ünitelerde içerik, öğrencide merak uyandirabilecek niteliktedir" sorusuna verilen cevaplara bakıldığında \%52,6'sını katılanlar, \%29,5'ini kararsızlar, \%17,9'unu katılmayanlar oluşturmaktadır. Buna göre örneklemde yer alan öğretmenler coğrafya kapsamlı ünitelerde içeriğin öğrencide merak uyandırabilecek nitelikte olduğunu düşünmektedir.

"Programda yer alan coğrafya içerikli kazanımlar, aralarında tutarl, sonrakinin oluşumuna destek dizilimine sahiptir" sorusuna verilen cevaplara bakıldığında \%48,4'ünü katılanlar, \%3,7'sini kararsızlar, \%37,9'unu katılmayanlar oluşturmaktadır. Buna göre örneklemde yer alan öğretmenler programda yer alan coğrafya içerikli kazanımların aralarında tutarlı, sonrakinin oluşumuna destek dizilimine sahip olduğunu düşünmektedir.

Sosyal Bilgiler Öğretmenlerinin, 5. Sınıf Sosyal Bilgiler Öğretim Programının Coğrafya Disiplinli Konuların İçeriğine İlişkin Görüşleri Nelerdir?

5. sınıf Sosyal Bilgiler Programı coğrafya disiplinli konuların içeriğine ilişkin öğretmen görüşleri ile ilgili olarak Tablo 3'te görüldüğü üzere "Bölgemizi Tanıyalım, ünitesinde iklim ve insan faaliyetleri konusunun yeterli seviyede verildiğini düşünüyorum" sorusuna verilen cevapların dağılımına bakıldığı zaman \%72'sini katılanlar, \%6,3'ünü kararsızlar, \%22,3'ünü katılmayanlar oluşturmaktadır. Buna göre öğretmenlerin çoğunluğu "Bölgemizi Taniyalım" ünitesinde iklim ve insan faaliyetleri konusunun yeterli seviyede verildiğini düşünmektedir. 
Tablo 3. Programın Değerlendirilmesi-Sosyal Bilgiler Öğretmenlerinin 5. Sınıf Sosyal Bilgiler Programının Coğrafya Disiplinli Konuların İçeriğine İlişkin Görüşleri

\begin{tabular}{|c|c|c|c|c|c|c|c|c|c|c|c|c|}
\hline & \multicolumn{2}{|c|}{ 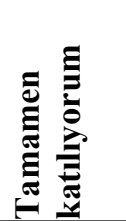 } & \multicolumn{2}{|l|}{ 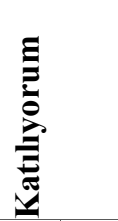 } & \multicolumn{2}{|c|}{$\underset{\Xi}{\mathbb{N}}$} & \multicolumn{2}{|l|}{ 泀 } & \multicolumn{2}{|c|}{ 范 } & \multicolumn{2}{|c|}{$\frac{\Xi}{\frac{\pi}{2}}$} \\
\hline & $\mathrm{F}$ & $\%$ & $\mathrm{~F}$ & $\%$ & $\mathrm{~F}$ & $\%$ & $\mathrm{~F}$ & $\%$ & $\mathrm{~F}$ & $\%$ & $\mathrm{~F}$ & $\%$ \\
\hline $\begin{array}{l}\text { Bölgemizi tanıyalım ünitesinde iklim } \\
\text { ve insan faaliyetleri konusunun yeterli } \\
\text { seviyede verildiğini düşünüyorum. }\end{array}$ & 14 & 15 & 54 & 57 & 6 & 6,3 & 15 & 16 & 6 & 6,3 & 95 & 100 \\
\hline $\begin{array}{l}\text { Yaşanacak yerler konusunda verilen } \\
\text { harita ve resimlerin öğretimi olumlu } \\
\text { etkilediğini düşünüyorum. }\end{array}$ & 11 & 12 & 57 & 60 & 5 & 5,3 & 18 & 19 & 4 & 4,2 & 95 & 100 \\
\hline $\begin{array}{l}\text { Ülkemizde afetler konusunun } \\
\text { içeriğinin öğrencilerde farkındalık } \\
\text { oluşturmaya yeterli olduğunu } \\
\text { düşünüyorum. }\end{array}$ & 4 & 4,2 & 65 & 68 & 9 & 9,5 & 16 & 17 & 1 & 1,1 & 95 & 100 \\
\hline $\begin{array}{l}\text { Ürettiklerimiz ünitesinde yer alan } \\
\text { bölgelerimizde ekonomik faaliyetler } \\
\text { konusunun yeterli seviyede verildiğini } \\
\text { düşünüyorum. }\end{array}$ & 6 & 6,3 & 41 & 43 & 16 & 17 & 28 & 30 & 4 & 4,2 & 95 & 100 \\
\hline $\begin{array}{l}\text { Ürettiklerimiz ünitesinde yer alan } \\
\text { insan ve ekonomi konusunun } \\
\text { ögrencilerde farkındalı oluşturduğunu } \\
\text { düşünüyorum. }\end{array}$ & 11 & 12 & 32 & 34 & 18 & 19 & 34 & 36 & & & 95 & 100 \\
\hline $\begin{array}{l}\text { Ürettiklerimiz ünitesinde yer alan } \\
\text { üretime katılalım, geleceğimizi } \\
\text { kurtaralım konusunun öğretimi olumlu } \\
\text { etkilediğini düşünüyorum. }\end{array}$ & 15 & 16 & 45 & 47 & 15 & 16 & 20 & 21 & & & 95 & 100 \\
\hline
\end{tabular}

"Ülkemizde afetler konusunun içeriğinin ögrencilerde farkındalık oluşturmaya yeterli olduğunu düşünüyorum" sorusuna verilen cevaplara bakıldığında \%72,2'sini katılanlar, \%9,5'ini kararsılar, \%18,1'ini katılmayanlar oluşturmaktadır. Buna göre örneklemde yer alan öğretmenler ülkemizde afetler konusunun içeriğinin öğrencilerde farkındalık oluşturmaya yeterli olduğunu düşünmektedir.

"Ürettiklerimiz ünitesinde yer alan insan ve ekonomi konusunun ögrencilerde farkındalık oluşturduğunu düşünüyorum” sorusuna verilen cevaplara bakıldığında \%46'sını katılanlar, \%19'unu kararsızlar, \%36'sını katılmayanlar oluşturmaktadır. Buna göre örneklemde yer alan öğretmenler Ürettiklerimiz ünitesinde yer alan insan ve ekonomi konusunun öğrencilerde farkındalık oluşturduğunu düşünmektedir.

Sosyal Bilgiler Öğretmenlerinin, 5. Sınıf Sosyal Bilgiler Öğretim Programının Konularında Yaşanılan Öğrenim Sürecine İlişkin Görüşleri Nelerdir?

5. sınıf Sosyal Bilgiler Programı coğrafya içerikli konularında yaşanılan öğrenim sürecine ilişkin öğretmen görüşleri ile ilgili olarak Tablo 4'te görüldüğü üzere "öğrenci merkezli eğitimögretimi uygulayabiliyorum" sorusuna verilen cevapların dağılımına bakıldığı zaman öğretmenlerin \%20'si çoğu zaman, \%76,8'i ara sıra uyguladıklarını, \%3,2'si hiçbir zaman uygulamadıklarını belirtmektedirler. Buna göre öğretmenlerin çoğunluğu coğrafya içerikli konularında öğrenci merkezli eğitim-öğretimi ara sıra uygulamaktadır. 
"Öğrenci kitaplarında coğrafya kapsaml konuların görsel olarak resim, grafik gibi unsurlarla anlatılması ögretimi olumlu etkilemektedir" sorusuna verilen cevapların dağılımına bakıldığ1 zaman öğretmenlerin \%74,7'si çoğu zaman, \%22,1'i ara sıra etkilediğini, \%3,2'si hiçbir zaman etkilediğini belirtmektedirler. Bu durum öğretmenlerin öğrenci kitaplarında coğrafya kapsamlı konuların görsel olarak resim, grafik gibi unsurlarla anlatılmasının öğretimi olumlu etkilediğini düşünmektedir.

Tablo 4. Öğretimin Değerlendirilmesi-Sosyal Bilgiler Öğretmenlerinin, 5. Sinıf Sosyal Bilgiler Öğretim Programının Konularında Yaşanılan Öğrenim Sürecine İlişkin Görüşleri

\begin{tabular}{|c|c|c|c|c|c|c|c|c|}
\hline & \multicolumn{2}{|c|}{ 㞭 } & \multicolumn{2}{|c|}{$\underset{\pi}{\pi}$} & \multicolumn{2}{|c|}{ 竭芯 } & \multicolumn{2}{|l|}{$\frac{\sqrt{3}}{\frac{\pi}{0}}$} \\
\hline & $\mathrm{F}$ & $\%$ & $\mathrm{~F}$ & $\%$ & $\mathrm{~F}$ & $\%$ & $\mathrm{~F}$ & $\%$ \\
\hline $\begin{array}{l}\text { Öğrenci merkezli eğitim-öğretimi } \\
\text { uygulayabiliyorum. }\end{array}$ & 19 & 20 & 73 & 76,8 & 3 & 3,2 & 95 & 100 \\
\hline $\begin{array}{l}\text { Öğrenci kitaplarında coğrafya kapsamlı } \\
\text { konuların görsel olarak resim, grafik gibi } \\
\text { unsurlarla anlatılması öğretimi olumlu } \\
\text { etkilemektedir. }\end{array}$ & 71 & 74,7 & 21 & 22,1 & 3 & 3,2 & 95 & 100 \\
\hline $\begin{array}{l}\text { Yapılandırmacı eğitim-öğretim yaklaşımını } \\
\text { coğrafya içerikli ünitelerde rahatlıkla } \\
\text { uygulayabiliyorum. }\end{array}$ & 16 & 16,8 & 79 & 83,2 & & & 95 & 100 \\
\hline $\begin{array}{l}\text { Ögrencinin bilgiye ulaşması yerine bilgiyi } \\
\text { direkt olarak veriyorum. }\end{array}$ & 30 & 31,6 & 57 & 60 & 8 & 8,4 & 95 & 100 \\
\hline $\begin{array}{l}\text { Anlatım, soru-cevap, örnek verme gibi } \\
\text { yöntemler yeterli oluyor. }\end{array}$ & 39 & 41,1 & 51 & 53,7 & 5 & 5,3 & 95 & 100 \\
\hline $\begin{array}{l}\text { Öğretirken kendi hazırladığım materyaller } \\
\text { yeterli oluyor. }\end{array}$ & 24 & 25,3 & 64 & 67,4 & 7 & 7,4 & 95 & 100 \\
\hline $\begin{array}{l}\text { Okulumuzun imkânsızlıkları nedeniyle araç } \\
\text { gereç sıkıntısı çekiyorum. }\end{array}$ & 24 & 25,3 & 45 & 47,4 & 26 & 27,4 & 95 & 100 \\
\hline VCD, tepegöz, bilgisayar kullanıyorum. & 34 & 35,8 & 51 & 53,7 & 10 & 10,5 & 95 & 100 \\
\hline $\begin{array}{l}\text { Grafik, resim, fotoğraf, gazete kupürleri } \\
\text { kullaniyorum. }\end{array}$ & 29 & 30,5 & 64 & 67,4 & 2 & 2,1 & 95 & 100 \\
\hline $\begin{array}{l}\text { Etkinlikleri öğretmen kılavuz kitabından ve } \\
\text { internetten yararlanarak hazırlıyorum. }\end{array}$ & 38 & 40 & 53 & 55,8 & 4 & 4,2 & 95 & 100 \\
\hline
\end{tabular}

"Yapılandırmacı ĕgitim-öğretim yaklaşımını coğrafya içerikli ünitelerde rahatlıkla uygulayabiliyorum" sorusuna verilen cevapların dağılımına bakıldığı zaman öğretmenlerin \%16,8'i çoğu zaman, \%83,2'si ara sıra uyguladıklarını belirtmektedirler. Buna göre öğretmenlerin çoğunluğu ara sıra yapılandırmacı eğitim-öğretim yaklaşımını coğrafya içerikli ünitelerde rahatlıkla uygulamaktadır.

"Öğrencinin bilgiye ulaşmast yerine bilgiyi direkt olarak veriyorum" sorusuna verilen cevapların dağılımına bakıldığı zaman öğretmenlerin \%31,6's1 çoğu zaman, \%60'1 ara sıra direkt olarak verdiği, \%8,4'ü hiçbir zaman bilgiyi direkt olarak vermediği belirtilmektedirler. Buna göre öğretmenlerin çoğunluğu öğrencilerine ara sıra bilgiyi direkt olarak verdiğini ifade etmektedir.

“Anlatım, soru-cevap, örnek verme gibi yöntemler yeterli oluyor" sorusuna verilen cevapların dağ 1 lımına bakıldığı zaman \%41,1'i çoğu zaman, \%53,7'si ara sıra yeterli olduğu, \%5,3'ü hiçbir zaman yeterli olmadığı belirtilmektedirler. Buna göre öğretmenler coğrafya içerikli konularda anlatım, soru-cevap, örnek verme gibi yöntemlerin ara sıra yeterli olduğunu 
düşünmektedir.

"Okulumuzun imkânsızlıkları nedeniyle araç gereç sıkıntısı çekiyorum" sorusuna verilen cevapların dağ1lımına bakıldığı zaman öğretmenlerin \%25,3'ü çoğu zaman, \%47,4'ü ara sıra sıkıntı çektiğini, \%27,4'ü hiçbir zaman sıkıntı çekmediğini belirtmektedirler. Buna göre öğretmenlerin 4/1'nin hala görev yaptı̆̆ 1 okulun imkânsızlıkları nedeniyle araç gereç sıkıntısı çektiği görülmektedir.

"Coğrafya içerikli konuları işlerken VCD, tepegöz, bilgisayar kullanıyorum" sorusuna verilen cevapların dağglımına bakıldığı zaman öğretmenlerin \%35,8'i çoğu zaman, \%53,7'si ara sıra kullandığını, \%10,5'i hiçbir zaman kullanmadığını belirtmektedirler. Buna göre öğretmenlerin büyük çoğunluğunun coğrafya içerikli konuları işlerken VCD, tepegöz, bilgisayar kullandığ görülmektedir.

Sosyal Bilgiler Öğretmenlerinin, 5. Sınıf Sosyal Bilgiler Öğretim Programının Coğrafya İçerikli Ünitelerinde Öğrencileri Üzerinde Meydana Gelen Değişmelere İlişkin Görüşleri Nelerdir?

5. sınıf Sosyal Bilgiler Programı coğrafya içerikli ünitelerde öğrencileri üzerinde meydana gelen değişmelere ilişkin öğretmen görüşleri ile ilgili olarak Tablo 5'te görüldüğü üzere haritalara daha fazla ilgi duyuyor, sorusuna verilen cevapların dağılımına bakıldığı zaman \%37,9'u arttı̆̆ını, \%45,3'ü aynı kaldığını, \%16,8'i azaldığını belirtmektedirler. Buna göre öğretmenler öğrencilerin haritalara olan ilgilerinin aynı kaldığını ifade etmektedir.

Tablo 5. Öğretimin Değerlendirilmesi - Sosyal Bilgiler Öğretmenlerinin, 5. Sınıf Sosyal Bilgiler Öğretim Programının Coğrafya İçerikli Ünitelerinde Öğrencileri Üzerinde Meydana Gelen Değiş̧melere İlişkin Öğretmen Görüşleri

\begin{tabular}{|c|c|c|c|c|c|c|c|c|}
\hline & \multicolumn{2}{|l|}{$\sum_{\bar{Z}}^{2}$} & \multicolumn{2}{|l|}{ 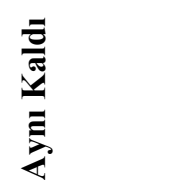 } & \multicolumn{2}{|l|}{$\frac{\bar{z}}{\mathrm{~N}}$} & \multicolumn{2}{|c|}{ 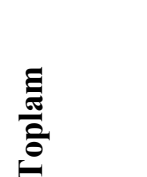 } \\
\hline & $\mathrm{F}$ & $\%$ & $\mathrm{~F}$ & $\%$ & $\mathrm{~F}$ & $\%$ & $\mathrm{~F}$ & $\%$ \\
\hline Haritalara daha fazla ilgi duyuyor. & 36 & 37,9 & 43 & 45,3 & 16 & 16,8 & 95 & 100 \\
\hline Grafikleri yorumlayabiliyor. & 39 & 41,1 & 47 & 49,5 & 9 & 9,5 & 95 & 100 \\
\hline $\begin{array}{l}\text { İnsan yaşami, ekonomi, yerleşme gibi } \\
\text { konularda iklim yer şekilleri vb. faktörleri } \\
\text { sorguluyor. }\end{array}$ & 49 & 51,6 & 46 & 48,4 & & & 95 & 100 \\
\hline Doğaya daha fazla değer veriyor. & 41 & 43,2 & 40 & 42,1 & 14 & 14,7 & 95 & 100 \\
\hline $\begin{array}{l}\text { Sektörler ile ülke gelişimi arasında ilgi } \\
\text { kurabiliyor. }\end{array}$ & 32 & 33,7 & 62 & 65,3 & 1 & 1,1 & 95 & 100 \\
\hline $\begin{array}{l}\text { Ülkemizin konumunun önemini daha iyi } \\
\text { kavrıyor ve uluslararası siyaseti takip ediyor. }\end{array}$ & 31 & 32,6 & 47 & 49,5 & 17 & 17,9 & 95 & 100 \\
\hline
\end{tabular}

"Coğrafya içerikli ünitelerde grafikleri yorumlayabiliyor" sorusuna verilen cevapların dağılımına bakıldığı zaman öğretmenlerin \%41,1'i arttığını, \%49,5'i aynı kaldığını, \%9,5'i azaldığını belirtmektedirler. Buna göre öğrencilerin grafikleri yorumlama konusunda öğretmenlerin yarısı aynı kaldığını ifade ederken, yarısına yakını da grafikleri yorumlama konusunda artış gösterdiğini düşünmektedir.

"Coğrafya içerikli ünitelerde öğrencilerinin İnsan yaşamı, ekonomi, yerleşme gibi konularda iklim yer şekilleri vb. faktörleri sorgulayabiliyor" sorusuna verilen cevapların dağılımına bakıldığg zaman öğretmenlerin \%51,6'sı arttığını, \%48,4'ü aynı kaldığını belirtmektedir- 
ler. Buna göre öğretmenlerin çoğunluğu coğrafya içerikli ünitelerde öğrencilerinin insan yaşamı, ekonomi, yerleşme gibi konularda iklim, yer şekilleri vb. faktörleri sorgulama konusunda artış olduğunu düşünmektedir.

Coğrafya içerikli ünitelerin öğrencilerin doğaya daha fazla değer vermesine etkisine bakıld1ğında örnekleme katılan öğretmenlerin \%43,2'si arttı̆̆ını, \%42,1'i aynı kaldığını, \%14,7'si azaldığını belirtmektedirler. Buna göre öğretmenlerin yarısına yakını öğrencilerinin doğaya daha fazla değer vermeye başladığını düşünmektedir.

5. Sınıf Sosyal Bilgiler Öğretim Programının Coğrafya İçerikli Ögelerine, Konulardaki Değişime, Konularında Yaşanılan Öğrenim Sürecine, Ünitelerinin Öğrencileri Üzerinde Meydana Gelen Değişmelere Dair Sosyal Bilgiler Öğretmenlerinin, Görüşlerinde Cinsiyete Göre Anlamlı Farklilıklar Var Midir?

Sosyal Bilgiler öğretmenlerinin 5. sınıf Sosyal Bilgiler Programının coğrafya içerikli ünitelerine ilişkin görüşlerinde cinsiyete göre anlamlı bir fark olup olmadığının tespiti için t-testi uygulanmıştır. Ortaya çıkan sonuçlar Tablo 6'da incelenmiştir.

Tablo 6. Sosyal Bilgiler Öğretmenlerinin 5. Sınıf Sosyal Bilgiler Programının Coğrafya İçerikli Ünitelerine İlişkin Görüşlerinin Cinsiyete Göre t-Testi Analizi

\begin{tabular}{|l|c|c|c|}
\hline \multicolumn{3}{|c|}{ Cinsiyete Göre T - testi } \\
\hline & $\mathrm{t}$ & $\mathrm{sd}$ & $\mathrm{p}$ \\
\hline Programın Değerlendirilmesinde &,- 500 & 93 &, 619 \\
\hline $\begin{array}{l}\text { Programın Değerlendirilmesi - 5. sınıf Sosyal Bilgiler } \\
\text { programı coğrafya içerikli konularında }\end{array}$ & $-1,985$ & 93 &, 050 \\
\hline $\begin{array}{l}\text { Öğretimin Değerlendirilmesinde } \\
\begin{array}{l}\text { Öğretimin Değerlendirilmesi - 2005 programının } \\
\text { coğrafya içerikli ünitelerinde }\end{array}\end{array}$ & 1,723 & 93 &, 088 \\
\hline p<.05 & 1,941 & 93 &, 055 \\
\hline
\end{tabular}

Tablodaki sonuçlara göre bu değerler Programın Değerlendirilmesinde (sig. ,619 p>.05), 5. sınıf Sosyal Bilgiler Programı coğrafya içerikli konularında (sig. ,050 p>.05), Öğretimin Değerlendirilmesinde (sig. ,088 p>.05), olarak görülmekteyken 2005 programının coğrafya içerikli ünitelerinde (sig. ,055 p>.05) olarak görülmektedir. Tüm bunlara bakarak Sosyal Bilgiler öğretmenlerinin 5. sınıf Sosyal Bilgiler Programının coğrafya içerikli ünitelerine ilişkin görüşlerinde cinsiyete göre anlamlı bir farklılık bulunmadı̆̆ görülmektedir.

5. Sınıf Sosyal Bilgiler Öğretim Programının Coğrafya İçerikli Ögelerine, Konulardaki Değişime, Konularında Yaşanılan Öğrenim Sürecine, Ünitelerinin Öğrencileri Üzerinde Meydana Gelen Değişmelere Dair Sosyal Bilgiler Öğretmenlerinin Görüşlerinde Hizmet Sürelerine Göre Anlamlı Farklılıklar Var Midır?

Sosyal Bilgiler öğretmenlerinin 5. sınıf Sosyal Bilgiler Programının coğrafya içerikli ünitelerine ilişkin görüşlerinde hizmet sürelerine göre anlamlı bir fark olup olmadığının tespiti için One-Way ANOVA testi uygulanmıştır. Ortaya çıkan sonuçlar Tablo 7'de incelenmiştir. 
Tablo 7. Sosyal Bilgiler Öğretmenlerinin 5. Sınıf Sosyal Bilgiler Programının Coğrafya İçerikli Ünitelerine İlişkin Görüşlerinin Hizmet Sürelerine Göre Varyans (One-Way ANOVA) Analizi

Hizmet Sürelerine Göre ANOVA Testi

\begin{tabular}{|c|c|c|c|c|c|}
\hline & & $\begin{array}{l}\text { Kareler } \\
\text { Toplamı }\end{array}$ & $\mathrm{sd}$ & $\mathrm{F}$ & $\mathrm{p}$ \\
\hline \multirow{3}{*}{ Programın Değerlendirilmesinde } & Gruplar Aras1 & 1414,954 & 5 & 1,491 & ,201 \\
\hline & Gruplar İçi & 16893,530 & 89 & & \\
\hline & Toplam & 18308,484 & 94 & & \\
\hline \multirow{3}{*}{$\begin{array}{l}\text { Programın Değerlendirilmesi - } 5 . \\
\text { sınıf Sosyal Bilgiler Programının } \\
\text { coğrafya içerikli konularında }\end{array}$} & Gruplar Arası & 209,108 & 5 & 1,733 &, 135 \\
\hline & Gruplar İçi & 2147,418 & 89 & & \\
\hline & Toplam & 2356,526 & 94 & & \\
\hline \multirow{3}{*}{ Öğretimin Değerlendirilmesinde } & Gruplar Aras 1 & 142,782 & 5 & 1,767 & ,128 \\
\hline & Gruplar İçi & 1438,376 & 89 & & \\
\hline & Toplam & 1581,158 & 94 & & \\
\hline \multirow{3}{*}{$\begin{array}{l}\text { Öğretimin Değerlendirilmesi - } 2005 \\
\text { programının coğrafya içerikli } \\
\text { ünitelerinde }\end{array}$} & Gruplar Aras1 & 178,150 & 5 & 6,205 &, 000 \\
\hline & Gruplar İçi & 511,050 & 89 & & \\
\hline & Toplam & 689,200 & 94 & & \\
\hline
\end{tabular}

Tablodaki sonuçlara göre bu değerler Programın Değerlendirilmesinde (sig. ,201 p>.05), 5. sınıf Sosyal Bilgiler programı coğrafya içerikli konularında (sig. , 135 p>.05) ve Öğretimin Değerlendirilmesinde (sig. ,128 p>.05) olarak görülmüş ve hizmet sürelerine göre anlamlı bir farklılık bulunmadığı anlaşılmıştır. Ancak bu değer 2005 programının coğrafya içerikli ünitelerinde (sig. , $000 \mathrm{p}<.05$ ) olarak tespit edilmiştir. Burada gruplar arasındaki farklılığın kaynağının tespiti içinde Tukey HSD testi uygulanmıştır. Ortaya çıkan sonuçlara göre hizmet süresine göre 1-5 yıl arasında görev yapanlar ile 5-10 yıl görev yapanlar arasında (sig. ,015 p<.05) anlamlı bir farklılık görülmektedir. Ayrıca 1-5 arasında görev yapanlar ile 11-15 yıl görev yapanlar arasında da (sig. ,000 p<.05) anlamlı bir farklılık görülmektedir.

5. Sınıf Sosyal Bilgiler Öğretim Programının Coğrafya İçerikli Ögelerine, Konulardaki Değişime, Konularında Yaşanılan Öğrenim Sürecine, Ünitelerinin Öğrencileri Üzerinde Meydana Gelen Değişmelere Dair Sosyal Bilgiler Öğretmenlerinin Görüşlerinde Mezun Olunan Bölüme Göre Anlamlı Farklılıklar Var Mıdır?

Sosyal Bilgiler öğretmenlerinin 5. sınıf Sosyal Bilgiler Programının coğrafya içerikli ünitelerine ilişkin görüşlerinde mezun olunan bölüme göre anlamlı bir fark olup olmadığının tespiti için One-Way ANOVA testi uygulanmıştır. Ortaya çıkan sonuçlar Tablo 8'de incelenmiştir. 
Tablo 8. Sosyal Bilgiler Öğretmenlerinin 5. Sınıf Sosyal Bilgiler Programının Coğrafya İçerikli Ünitelerine İlişkin Görüşlerinin Mezun Olunan Bölüme Göre Varyans (One-Way ANOVA) Analizi

Mezun Olunan Bölüme Göre ANOVA Testi

\begin{tabular}{|c|c|c|c|c|c|}
\hline & & $\begin{array}{l}\text { Kareler } \\
\text { Toplamı }\end{array}$ & $\mathrm{sd}$ & $\mathrm{F}$ & $\mathrm{p}$ \\
\hline \multirow{3}{*}{ Programın Değerlendirilmesinde } & Gruplar Arası & 2553,708 & 4 & 3,647 & ,008 \\
\hline & Gruplar İçi & 15754,777 & 90 & & \\
\hline & Toplam & 18308,484 & 94 & & \\
\hline \multirow{3}{*}{$\begin{array}{l}\text { Programın Değerlendirilmesi - } 5 . \\
\text { sınıf Sosyal Bilgiler Programı } \\
\text { coğrafya içerikli konularında }\end{array}$} & Gruplar Arası & 240,153 & 4 & 2,553 & ,044 \\
\hline & Gruplar İçi & 2116,374 & 90 & & \\
\hline & Toplam & 2356,526 & 94 & & \\
\hline \multirow{3}{*}{ Öğretimin Değerlendirilmesinde } & Gruplar Arası & 54,459 & 4 &, 803 &, 527 \\
\hline & Gruplar İçi & 1526,699 & 90 & & \\
\hline & Toplam & 1581,158 & 94 & & \\
\hline \multirow{3}{*}{$\begin{array}{l}\text { Öğretimin Değerlendirilmesi- } 2005 \\
\text { programının coğrafya içerikli } \\
\text { ünitelerinde }\end{array}$} & Gruplar Arası & 94,439 & 4 & 3,573 & ,609 \\
\hline & Gruplar İçi & 594,761 & 90 & & \\
\hline & Toplam & 689,200 & 94 & & \\
\hline
\end{tabular}

Tablodaki sonuçlara göre bu değerler Programın Değerlendirilmesinde (sig. ,008 p<.05) ve 5 . sınıf Sosyal Bilgiler programının coğrafya içerikli konularında (sig. ,044 $\mathrm{p}<.05$ ) olarak tespit edilmiş ve Sosyal Bilgiler öğretmenlerinin görüşlerinde mezun olunan bölüme göre anlamlı bir farklılık olduğu görülmüştür. Burada gruplar arasındaki farklılığın kaynağının tespiti içinde Tukey HSD testi uygulanmıştır. Ortaya çıkan sonuçlara bakıldığında Programın Değerlendirilmesinde Sosyal Bilgiler öğretmenleri ile Coğrafya Bölümü mezunlarının görüşleri arasında (sig. , 039 p <.05) anlamlı bir farklılık görülmektedir. Ayrıca 5. sınıf Sosyal Bilgiler Programının coğrafya içerikli konularında Sosyal Bilgiler öğretmenleri ile Coğrafya Bölümü mezunlarının görüşleri arasında da (sig. ,036 p<.05) anlamlı bir farklılık görülmektedir.

Ancak bu değer Öğretimin Değerlendirilmesinde (sig. ,527 p>.05) ve 2005 programının coğrafya içerikli ünitelerinde (sig. ,609 p<.05) olarak tespit edilmiş ve Sosyal Bilgiler öğretmenlerinin görüşlerinde mezun olunan bölüme göre anlamlı bir farklılık olmadığ görülmüştür.

Araştırma Sırasında Kullanılan Anket Çalışmasının Sonunda Eklemek İstediğiniz Görüşleriniz Kısmına Örnekleme Katılan Öğretmenlerimizin Belirttikleri Görüşler:

"Sosyal Bilgiler alanının en büyük problemi zamandır. Çok konuyu az zamanda anlatmaya çalışlyoruz. Bu da ĕgitim öğretimde aksakliklara neden oluyor."

"Bu ögretim programında tarih ve coğrafya konularının kitapta konu bazında dă̆ınık olması; bir tarih, bir coğrafya geçişli konular konu bütünlüğünü bozmaktadır. Eskiden uygulanan Millî Tarih ve Millı Coğrafya tarzı bir ders getirilmesi yerinde olur. En azından öğrenci Millı̂ Coğrafya dersinde coğrafya konularını bir bütün halinde görür." 
"Müfredatta cŏgrafya konulart yetersiz kallyor. Coğrafya öğretiminde alan gezilerine ăgırlı verilmeli. Coğrafya konuları müfredatta yeteri kadar yer almıyor. Çok dar alınmış. Daha fazla konular ve görsellerle güzelleşebilir. Görsel harita gibi konulara ağırlık verilmesi, grafiklerin anlatılması gerekiyor diye düşünüyorum."

"Dersleri farklı şekillerde işlemek özellikle alan gezileri klasik idareciler tarafindan pek sıcak karşılanmiyor. Coğrafya dersi en etkin yerinde gözlemlenerek ögrreniliyor. Fakat bu konuda okul idarecilerinin ilgilerinin artırlmast ve cesaretlendirilmeleri gerekiyor."

"Sosyal Bilgiler genel olarak ögrencinin pek de ilgi göstermediği dersler arasında. Bu yüzden çok farkl, eğlenceli etkinlikler eklenerek öğrencilerin ilgisi artırllabilir. Derste izletilebilecek coğrafya konularının işlendiği ĕglenceli animasyonlar olsa çok daha verimli olacă̆ını düşünüyorum. Yenidünya sisteminde artık herkes sinemanın nimetlerinden faydalanabiliyor. coğrafyayı sevdirecek sinemalar yapılsa çok iyi olur (Evliya Çelebi, Piri Reis'in animasyon filmi gibi)."

\section{Sonuç, Tartışma ve Öneriler}

Sosyal Bilgiler öğretmenlerinin Sosyal Bilgiler Programının coğrafya içerikli ünitelerine ilişkin görüşlerini belirlemek amacıyla yapılan bu çalışmada tarama yöntemi kullanılmıştır. Bu model çerçevesinde, ilköğretim okullarında görev yapan Sosyal Bilgiler öğretmenlerinin konu ile ilgili görüş ve önerileri ortaya konulmaya çalış1lmıştır. Sosyal Bilgiler öğretmenlerinin büyük çoğunluğu 2005 Sosyal Bilgiler Programının eğitime olumlu katkıda bulunduğunu düşünmektedir.

Sosyal Bilgiler öğretmenlerinin yarısı öğretim programında coğrafya konularına yeterli pay ayrıldığını düşünürken yarıya yakını coğrafya konularına yeterli pay ayrılmadığını düşünmektedir. Bu oran Kahriman'ın (2008) 6. sınıf Sosyal Bilgiler dersi ile alakalı çalışmasında da yarıya yakın çıkmıştır. Buradan hareketle Sosyal Bilgiler Programı içerisinde coğrafya konularına daha fazla yer verilebilir.

Sosyal Bilgiler öğretmenlerinin yarısı programda coğrafya içerikli konuların kendi içinde bütünlük gösterdiğini düşünürken, yarıya yakını coğrafya içerikli konuların kendi içinde bütünlük göstermediğini düşünmektedir.

Sosyal Bilgiler öğretmenlerinin yarıdan fazlası coğrafya kapsamlı ünitelerde içeriğin, öğrencide merak uyandırabilecek nitelikte olduğu görüşünü savunmakta iken beşte biri bu görüşe katılmadığını ifade etmektedir. Buna göre öğretmenlerin çoğu coğrafya kapsamlı ünitelerde içeriğin öğrencide merak uyandırabilecek nitelikte olduğunu düşünmektedir.

Sosyal Bilgiler öğretmenlerinin yarıdan fazlası coğrafya içerikli becerilerin seçiminin doğru yapıldığını düşünmekte iken beşte biri bu görüşe katılmadığını ifade etmektedir. Bununla birlikte yarıya yakını coğrafya içerikli kavramların seçiminin doğru yapıldığını düşünürken dörtte biri bu görüşe katılmamaktadır.

Sosyal Bilgiler öğretmenlerinin yarıya yakını programda yer alan coğrafya içerikli kazanımların aralarında tutarlı, sonrakinin oluşumuna destek dizilimine sahip olduğunu düşünmekte iken, üçte biri bu düşünceye katılmamaktadır. Bu düşünceye katılmayanların oranı Kahriman'ın (2008) 6. sınıf programında dörtte bir olarak karşımıza çıkmaktadır. Dolayısıyla coğrafya içerikli kazanımların aralarında tutarlı, sonrakinin oluşumuna destek dizilimine sahip olması ögrenmeye olumlu etki edecektir. 
Sosyal Bilgiler Öğretmenlerinin, 5. Sınıf Sosyal Bilgiler Öğretim Programının Coğrafya Disiplinli Konuların İçeriğine İlişkin Görüşleri Çerçevesinde Ortaya Çıkan Sonuçlar;

Sosyal Bilgiler öğretmenlerinin dörtte üçüne yakını "Ülkemizde Afetler" konusunun içeriğinin öğrencilerde farkındalık oluşturmaya yeterli olduğunu düşünmekteyken, dörtte birine yakını afetler konusunun içeriğinin öğrencilerde farkındalık oluşturmaya yeterli olmadığını düşünmektedir. Çepni'nin (2011) "Sosyal Bilgiler Öğretim Programinda Yer Alan Coğrafya Kavramlarına İlişkin Ögrrenci Algılarının İncelenmesi" adlı araştırmasında, sosyo-ekonomik düzey farkı gözetilmeksizin katılımcıların büyük bir çoğunluğunun afet kavramını; "yok oluşa sebebiyet veren, olumsuzlukları beraberinde getiren, telafisi zor olan ve zamansiz meydana gelebilen" şeklinde algıladıkları belirtilmektedir. Ülkemizin afetler, özellikle deprem ve sel felaketleri konusunda bir hayli hareketli bir coğrafyaya sahip olduğunu düşündüğümüzde afetler konusunda küçük yaşta farkındalık oluşturmak için daha fazla zaman ve etkinliklere yer verilmelidir.

Sosyal Bilgiler öğretmenlerinin yarısına yakını "Ürettiklerimiz" ünitesinde yer alan insan ve ekonomi konusunun öğrencilerde farkındalık oluşturduğunu düşünmekteyken üçte biri bu görüşe katılmamıştır. Bununla birlikte öğretmenlerin üçte ikisi "Ürettiklerimiz" ünitesinde yer alan "Üretime Katılalım, Geleceğimizi Kurtaralım" konusunun öğretimi olumlu etkilediğini düşünürken sadece dörtte biri bu görüşe katılmamaktadır. Bu konu ile alakalı olarak Kahriman'ın (2008) çalışmasında Türkiye'nin ithalat ve ihracat faaliyetlerine yer verilmesinin öğretimi olumlu etkilediğini düşünen öğretmenlerin oranı da yüzde seksen yedi civarındadır. Tüm bu sonuçlara bakarak üretim ve millî ekonomi konusunda küçük yaşta farkındalık oluşturmanın önemi ortaya çıkmaktadır.

Sosyal Bilgiler Öğretmenlerinin, 5. Sınıf Sosyal Bilgiler Öğretim Programının Konularında Yaşanılan Öğrenim Sürecine İlişkin Görüşleri Çerçevesinde Ortaya Çıkan Sonuçlar:

Sosyal Bilgiler öğretmenlerine göre, 5. sınıf Sosyal Bilgiler Öğretim Programı coğrafya içerikli konularında yaşanılan öğrenim sürecinde, öğrenci merkezli eğitim ile materyal kullanımı ve kılavuz kitaptan yapılan etkinlikler dersin görselliğini arttırsa da zaman zaman geleneksel yöntemlere dönülmektedir. Örnekleme katılan öğretmenlerin yüzde otuz dokuzunun hizmet sürelerinin 11 yıl ve üzerinde (2005 öncesi) olduğunu düşündüğümüzde 2005 programından önce mesleğe başlayanların bu oranı yükselttiği düşünülebilir.

Öğretmenlerin çoğunluğu öğrenci kitaplarında coğrafya kapsamlı konuların görsel olarak resim, grafik gibi unsurlarla anlatılması öğretimi çoğu zaman olumlu yönde etkilediğini belirtmekte, yapılandırmacı eğitim-öğretim yaklaşımını coğrafya içerikli ünitelerde ara sıra uygulayabilmektedir. Kahriman'ın (2008) araştırmasına göre de öğretmenlerin çoğunluğu öğrenci kitaplarında coğrafya kapsamlı konuların görsel olarak resim, grafik gibi unsurlarla anlatılmas1nın öğretimi çoğu zaman olumlu yönde etkilediğini, yapılandırmacı eğitim-öğretim yaklaşımını coğrafya içerikli ünitelerde ara sıra uygulanabildiğini belirtmektedir. Yıldırım'ın (2006) araştırmasına göre de öğretmenler Hayat Bilgisi ders kitaplarında kullanılan renklerin öğrencilerin motivasyonunu arttırdığını düşünmektedir. Öğretmenlerin yarıdan fazlası coğrafya içerikli konularda öğrenci merkezli eğitim öğretimi ara sıra uygulamaktadırlar. Sağlam (2006), davranışçı ve yapılandırmacı Sosyal Bilgiler öğretim uygulamalarına göre öğretmen ve öğrenci görüşlerine dair yaptığı araştırmanın sonucunda, yapılandırmacı Sosyal Bilgiler öğretim uygulamalarının motivasyon, içerik ve eğitim durumu boyutlarında etkili olduğu sonucuna varmıştır.

Öğretmenlerin çoğunluğu öğrencilerin bilgiye ulaşması yerine bilgiyi ara sıra direkt olarak verdiğini, slogan bulma, KH oluşturma, alan gezileri gibi yöntemleri ara sıra kullandıklarını belirtmektedir. Özdal'ın (2007) araştırma sonuçlarına göre; Sosyal Bilgiler öğretmenlerinin, 
"Türkiyemiz" ünitesini işlerken farklı strateji, yöntem, teknik ve araç-gereçleri kısmen kullandıkları ve bu ünitelerin anlatımında daha çok soru-cevap yönteminin, daha sonra düz anlatım yönteminin ve en azda proje yöntemi ile gezi-gözlem yönteminin kullanıldı̆̆ı ve Sagay'ın (2007) araştırma sonuçlarına baktığımızda coğrafya konularının öğretilmesinde en etkili yöntemlerden biri olan gezi gözlem yönteminin öğretmenler tarafından yeterince kullanılmadığı tespit edilmiş, bu sonuçlar bizim araştırmamızla da uyuşmaktadır. Ayrıca Kahriman'ın (2008) araştırmasıyla kısmen de olsa paralellik gösteren araştırmamızın bulgularına göre coğrafya disiplinli konularda daha çok anlatım yöntemi kullanılmaktadır. Ancak anlatım yönteminin kalıcı öğrenmesinin oluşmasında etkisinin (\%5) çok az olduğu düşünülürse Sosyal Bilgiler ve Coğrafya derslerinin öğrenciler tarafından az sevilmesinin nedenleri daha iyi anlaşılır.

Sosyal Bilgiler Öğretmenlerinin, 5. Sınıf Sosyal Bilgiler Öğretim Programının Coğrafya İçerikli Ünitelerinde Öğrencileri Üzerinde Meydana Gelen Değişmelere İlişkin Görüşleri Çerçevesinde Ortaya Çıkan Sonuçlar:

Öğrenciler; yorum, sorgulama, neden-sonuç ilişkisi kurma, doğaya değer verme gibi beceriler kazanmıştır. Öğretmenlerin büyük çoğunluğu öğrencilerinin doğaya daha fazla değer verdiğini düşünmektedir. Ayrıca öğretmenlerin çoğunluğu öğrencilerin de grafikleri yorumlayabilmelerinde ve insan yaşamı, ekonomi, yerleşme gibi konularda iklim, yer şekilleri vb. faktörleri sorgulayabilmelerinde artış olduğunu düşünmektedir.

Sosyal Bilgiler öğretmenlerinin çoğunluğu coğrafya içerikli ünitelerin öğrencilerin sektörler ile ülke gelişimi arasında ilgi kurabilmesine olan etkisinde herhangi bir değişikliğin olmadığını düşünürken üçte biri söz konusu etkide artış olduğunu düşünmektedir. Bunun yanında coğrafya içerikli ünitelerin öğrencilerin ülkemizin konumunun önemini daha iyi kavraması ve uluslararası siyaseti takip etmesine etkisine bakıldığında öğretmenlerin üçte biri artış olduğunu, yarısı aynı kaldığını ifade etmektedir.

Araştırma Sırasında Kullanılan Anket Çalışmasının Sonunda Eklemek İstediğiniz Görüşleriniz Kısmına Örnekleme Katılan Öğretmenlerimizin Belirttikleri Görüşler ve Yorumlar;

"Sosyal Bilgiler alanının en büyük problemi zamandır. Çok konuyu az zamanda anlatmaya çalışıyoruz. Bu da eğitim öğretimde aksakliklara neden oluyor."

Sosyal Bilgiler programı incelediği zaman kendi içinde birçok disiplinin yer aldığı ve her geçen gün daha genişlediği görülmektedir. Bunun yanında Sosyal Bilgiler için ayrılan zaman artmayınca aksaklıkları beraberinde getirmektedir. Ayrıca bu düşünce, Sagay'ın (2007) yaptığ1 araştırmada, Sosyal Bilgiler derslerine haftada 3 saatin ayrılmasının müfredatın yetiştirilmesi açısından yetersiz olduğu ve bu ders saati içerisinde coğrafya ünitelerine yeterli zamanın ayrılmadığı sonucuyla uyuşmaktadır.

"Bu ögretim programında tarih ve coğrafya konularının kitapta konu bazında dağınık olması; bir tarih, bir coğrafya geçişli konular konu bütünlügünü bozmaktadır. Eskiden uygulanan Millî Tarih ve Millî Coğrafya tarzı bir ders getirilmesi yerinde olur. En azından öğrenci Millî Coğrafya dersinde coğrafya konularını bir bütün halinde görür."

Bu görüş Sagay'ın (2007) yaptığı araştırmada, araştırmaya katılan öğretmenlerin, ilköğretim Sosyal Bilgiler dersi öğretim programında tarih ve coğrafya konularının ayrı birer disiplin olarak okutulmasının daha yararlı olacağını düşündükleri sonucuyla paralellik göstermektedir.

"Müfredatta coğrafya konuları yetersiz kalıyor. Coğrafya öğretiminde alan gezilerine ă̆ırlık verilmeli. Coğrafya konuları müfredatta yeteri kadar yer almıyor. Çok dar alınmış. Daha fazla konular ve görsellerle güzelleşebilir. Sosyal Bilgiler öğretim programı gözden geçirilmeli. Gereksiz konuların fazla olduğunu düşünüyorum. Konular tam anlamıyla Sosyal Bilgileri 
kapsamıyor."

Araştırmamıza katılan öğretmenlerimizin bu görüşleri Sagay'ın (2007) yaptığı araştırmada, ilköğretim Sosyal Bilgiler programında yer alan coğrafya ünitelerinin coğrafya disiplinlerinin öğretilmesi açısından yetersiz olduğu sonucuyla örtüşmektedir.

"Görsel harita gibi konulara ağıllı verilmesi, grafiklerin anlatılmast gerekiyor diye düşünüyorum. Görseller ögrencilerin yaş ve seviyesine daha fazla hitap eder olmalı. Bazı ünitelerde çok yavan ve yetersiz kallyor. Bilgisayar ve internetin yaygin olduğu bu zamanda interaktif ögretim uygulamaların eşlik ettiği bir eğitim sistemi olmal.."

Bu konuda Urçar'ın (2011) araştırmasında, altıncı sınıf Sosyal Bilgiler ders kitabında yer alan coğrafya konularının içeriği yeniden gözden geçirilmeli, görsel öğeler ile zenginleştirilmeli ve altıncı sınıf Sosyal Bilgiler ders kitabında coğrafya konularının öğrenci seviyesine uygunluğu tartış1labilir sonucuyla paralellik göstermektedir.

"Dersleri farkl şekillerde işlemek özellikle alan gezileri klasik idareciler tarafindan pek sicak karşılanmiyor. Coğrafya dersi en etkin, yerinde gözlemlenerek ögreniliyor. Fakat bu konuda okul idarecilerinin ilgilerinin artırlmast ve cesaretlendirilmeleri gerekiyor."

Son zamanlarda yerel yönetimlerin özellikle belirli gün ve haftalarda (18 Mart, 23 Nisan, 19 Mayıs vb.) öğrenciler için geziler düzenlediği görülmekle birlikte yeterli değildir. Alan gezileri konusunda hem öğretmenlerin hem de idarecilerin cesaretlendirilmeleri gerekiyor.

Aslında bilginin bugünkü üretim hızı karşısında okullarımızda çok az olgu geçerliliğini koruyabilir durumdadır. Bu nedenle okul yaşantısı, bir anlamda sadece ezbere ve tüketiciliğe dayalı olursa boşa gitmiş olacaktır. Çünkü bilgi bizim onu yaymamızdan daha hızlı üretiliyor. Bir bakıma elektronik hızda bilgi üretilirken alışılagelmiş ders kitapları aracılığ 1 ile bilgiyi yaymaya çalışmak pek akılcı olmasa gerek. Bu bağlamda denilebilir ki coğrafyada bilginin yapı taşları olan olgu, kavram ve genellemeleri içeren bilginin nasıl üretileceği fikrini yakalamış bir öğrenci modeli oluşturmak durumundayız. Öyleki artık öğrenciler, görevlerinin bilgi edinmenin yanında bilgi üretmek olduğunu da anlamalılar (Taşl1 1997). Buna karşılık öğretmenler de bilgi nakletme yerine öğrencilerine bilginin üretilme yollarında yardımcı olma bilincini kazanmalıdırlar.

Okulların bilgisayar, projeksiyon, televizyon, VCD-DVD oynatıcı, tepegöz gibi teknik eksiklikleri giderilmelidir. Bu konuda sivil toplum ve meslek odalarından daha fazla destek alınabilir. Etkinlikler daha da geliştirilerek sosyo-ekonomik farklılıklara göre de düzenlenmelidir. Bakanlığın merkez teşkilatında görev yapan uzmanların bu konuda gerekli çalışmayı yapması gerekmektedir. Etkinliklerin artması öğrencilerin derse olan motivasyonlarını arttırmada önemli rol oynar. Öğrenci çalışma kitaplarındaki etkinlikler kazanımlara ulaşmada önemli bir araçtır. Ancak görsellikten uzak, yazıya boğulmuş, acele ve özensiz hazırlanmış bazı etkinlikler yetersiz kalmaktadır. Öğrenci çalışma kitabı çok daha titiz hazırlanmalı, kazanımlar göz önünde bulundurulmalıdır.

"Sosyal Bilgiler genel olarak ögrencinin pek de ilgi göstermediği dersler arasinda olduğu için çok farkll, eğlenceli etkinlikler eklenerek öğrencilerin ilgisi artırılabilir. Derste izletilebilecek coğrafya konularının işlendiği ĕglenceli animasyonlar olsa çok daha verimli olacağını düşünüyorum. Yenidünya sisteminde artık herkes sinemanın nimetlerinden faydalanabiliyor. Coğrafyayı sevdirecek sinemalar yapılsa çok iyi olur. Evliya Çelebi, Piri Reis'in animasyon filmi gibi."

Coğrafya içerikli konularda yaşanılan öğrenim sürecinde, yapılandırmacı öğretim modelinin ara sıra uygulanıyor olması öğretmenlerimizin hala geleneksel yönteme ilgilerinin fazla olduğu anlamına gelir. Öğretmenlerimizin öğrenci merkezli eğitim uygulamaları konusunda gerek 
hizmet içi eğitimlerle gerekse zümrelerle ilgi ve cesaretleri arttırılmalıdır.

Ülkemizin afetler, özellikle deprem ve sel felaketleri konusunda bir hayli hareketli bir coğrafyaya sahip olduğunu düşündüğümüzde afetler konusunda küçük yaşta farkındalık oluşturmak için daha fazla zaman ve etkinliklere yer verilmelidir.

Sosyal Bilgiler programının yoğun içeriğinin göz önünde bulundurularak özellikle coğrafya içeriği açısından ayrılan zamanın gözden geçirilerek arttırılması gerekmektedir.

Öğrenci kitaplarında ve çalışma kitaplarında testlere daha çok yer verilmelidir. Hem kentlerde hem de özellikle kırsal kesimde firsat eşitliğini sağlayabilmek için bu konuda destek olabilecek yayımlar hazırlanmalıdır.

Dünyayı ve ülkesini tanımasından, olayları farklı yorumlarla izleyebilmesine kadar coğrafyanın bireylere kazandırdığı unsurlar unutulmamalı gerek Sosyal Bilgilerin tüm dersler arasında gerekse de coğrafya içerikli tüm ögelerin Sosyal Bilgiler içindeki payı arttırılmalıdır.

\section{KAYNAKÇA}

Ata B. (2006). "Sosyal Bilgiler Öğretim Programı”. Ed. Cemil Öztürk. Hayat Bilgisi ve Sosyal Bilgiler Öğretimi (2006) 71-83. Ankara.

Atalay İ. (1994). Genel Fiziki Coğrafya. İzmir 1994.

Barth J. L. \& Demirtaş A. (1997). İlköğretim Sosyal Bilgiler Öğretimi. Ankara 1997.

Çepni O. (2011). Sosyal Bilgiler Öğretim Programında Yer Alan Coğrafya Kavramlarına İlişskin Öğrenci Algılarının İncelenmesi. Yayımlanmamış Doktora Tezi. Gazi Üniversitesi, Eğitim Bilimleri Enstitüsü, Ankara 2011.

Doğanay H. (1989). “Coğrafya ve Liselerimizde Coğrafya Öğretim Programları”. Coğrafya Araşttrmaları (Atatürk Kültür, Dil ve Tarih Yüksek Kurumu, Coğrafya Bilim ve Uygulama Kolu Yayını) IX/1 (1989) 7-24.

Doğanay H. \& Sever R. (2011). Genel ve Fiziki Coğrafya. Ankara 2011.

Efe R. (1996). "Coğrafyada Yeni Yaklaşımlar, Coğrafya Eğitiminde Çağdaş Metod ve Teknikler". Marmara Coğrafya Dergisi 1 (1996) 135-149.

Gelen İ. (2002). "Sınıf Öğretmenlerinin Sosyal Bilgiler Derslerinde Düşünme Becerilerini Kazandırma Yeterliliklerinin Değerlendirilmesi”. Çukurova Üniversitesi Sosyal Bilimler Enstitüsü Dergisi 10 (2002) 100-117.

Gençtürk E. (2009). İlköğretim Sosyal Bilgiler Öğretmen Adaylarının Coğrafya Okuryazarlık Düzeylerinin Belirlenmesi. Yayımlanmamış Doktora Tezi. Gazi Üniversitesi, Eğitim Bilimleri Enstitüsü, Ankara 2009.

Kahriman M. (2008). 6. Sinıf Sosyal Bilgiler Programının Coğrafya İçerikli Ünitelerine İlişsin Sosyal Bilgiler Öğretmenlerinin Görüşleri. Yayımlanmamış Yüksek Lisans Tezi. Selçuk Üniversitesi, Sosyal Bilimler Enstitüsü, Konya 2008.

Karabağ S. (1998). "Coğrafya Öğretiminde Anahtar Sorular ve Kavramlar". Gazi Eğitim Fakültesi Dergisi 18/2 (1998) 25-41.

Kocalar A. O. \& Demirkaya H. (2014). "Coğrafya Öğrenmek Niçin Önemlidir? Lise Öğrencilerinin Algıları”. Doğu Coğrafya Dergisi 32 (2014) 123-144.

Milli Eğitim Bakanlığı (MEB). (2005). Sosyal Bilgiler 4.-5. Sinff Programı. Ankara 2005.

Özdal H. (2007). İlköğretim 6. Sinıf Sosyal Bilgiler Ders Programında Yer Alan Türkiye'miz Ünitesinin Öğretmen Görüslerine Göre Değerlendirilmesi. Yayımlanmamış Yüksek Lisans Tezi. Sakarya Üniversitesi, Sosyal Bilimler Enstitüsü, Sakarya 2007.

Özdemir D. (2006). Sosyal Bilgiler Dersinin Düsünme Becerilerini Kazandırma Düzeylerine İlişskin Öğretmen Görüşleri. Yayımlanmış Yüksek Lisans Tezi. Anadolu Üniversitesi, Eğitim Bilimleri Enstitüsü, Eskişehir 2006.

Sagay N. (2007). İlköğretim II. Kademe Sosyal Bilgiler Derslerinde Coğrafya Konularının Öğretimi: 
Problem ve Öneriler. Yayımlanmamış Yüksek Lisans Tezi. Afyon Kocatepe Üniversitesi, Sosyal Bilimler Enstitüsü, Afyon 2007.

Sağlam H. İ. (2006). Türkiye'deki Davranışçı ve Yapılandırmacı Sosyal Bilgiler Öğretim Uygulamalarının Değerlendirilmesi. Yayımlanmamış Doktora Tezi. Atatürk Üniversitesi, Sosyal Bilimler Enstitüsü, Erzurum 2006.

Şahin K. (2003). "İlk ve Ortaöğretimde Coğrafya Müfredat Programlarının Geliştirilmesi”. Kastamonu Ĕgitim Dergisi 11/1 (2003) 81-92.

Taşlı İ. (1997). Öğrenci Merkezli Yöntemlerle Coğrafya Öğretimi. Yayımlanmamış Doktora Tezi. Dokuz Eylül Üniversitesi, Sosyal Bilimler Enstitüsü, İzmir 1997.

Tay B. (2004). "Sosyal Bilgiler Dersinde Anlamlandırma Stratejilerinin Yeri ve Önemi". Gazi Üniversitesi Kırşehir Eğitim Fakültesi Dergisi 5/2 (2004) 1-12.

Urçar A. (2011). Altıncı Sinıf Sosyal Bilgiler Ders Kitabında Yer Alan Coğrafya Konularının Öğretim Sürecine Yönelik Öğretmen Görüşlerinin İncelenmesi (Erzurum İli Aşkale İlçesi Örneği). Yayımlanmamış Yüksek Lisans Tezi. Atatürk Üniversitesi, Eğitim Bilimleri Enstitüsü, Erzurum 2011.

Yıldırım A. (2006). Yeni İlköğretim Programına Göre Hazırlanmış Hayat Bilgisi Ders Kitaplarına İlişkin Öğretmen Görü̈slerinin İncelenmesi (Elazığ İli Örneği). Yayımlanmamış Yüksek Lisans Tezi. Fırat Üniversitesi, Sosyal Bilimler Enstitüsü, Elazığ 2006. 